\title{
THE STUDY OF PADEKI KORRU FROM ISLAMIC LAW PERSPECTIVE
}

\section{PADEKI KORRU PERSPEKTIF HUKUM ISLAM}

\author{
Siti Erna ${ }^{1}$, Muhimatul Kibtiyah ${ }^{2}$, Izzul Madid ${ }^{3}$, Supriyanto ${ }^{4}$ \\ Kemenag Kab Sumba Barat ${ }^{1}$, Balai Diklat Keagamaan Surabaya², \\ Ma'had Ali Salafiyah Syafi'iyah Situbondo33, M a'had Ali Salafiyah Syafi'iyah Situbondo ${ }^{4}$, \\ *corresponding author : muhimatul.kibtiyah@gmail.com \\ DOI: https://doi.org/10.52048/inovasi.v15i1.249
}

\begin{abstract}
This study was based on the tradition of the Sumba people touching their noses when meeting, commonly called Padeki Korru, carried out against people of the same sex or the opposite sex and has been carried out from generation to generation. The purpose of this study is to find out the views of Islamic law regarding the adat tradition of Padeki Korru. This study used a qualitative approach, with 12 sources of the population of West Sumba who were Muslims, non-Muslims, and Muallaf. This research shows that the Padeki Korru Tradition is a forbidden tradition, because it is out of the sharia provisions in the prohibition of touching non-mahrams. When viewed from the point of being a form of religious tolerance and avoiding gossip that is feared will lead to conflict, the researcher directs this to the second level of emergency, namely only in a state of urgency is allowed to practice traditions
\end{abstract}

Keywords: Islam Perspektif, Padeki Korru, Sumba Tradition

\section{ABSTRAK}

Kajian ini dilatarbelakangi tradisi masyarakat Sumba yang saling menyentuhkan hidung saat bertemu, biasa disebut Padeki Korru, dilakukan terhadap kaum sejenis atau lawan jenis dan telah dilakukan turun temurun. Tujuan kajian ini adalah ingin mengetahui pandangan hukum Islam mengenai tradisi adat Padeki Korru. Penelitian ini menggunakan pendekatan kualitatif, dengan narasumber penduduk Sumba Barat beragama Islam, non-Muslim dan Muallaf sebanyak 12 orang. Penelitian ini mendapatkan hasil bahwa tradisi Padeki Korru ini merupakan 'urf yang fâs id karena keluar dari ketentuan syariat dalam hal larangan menyentuh kepada yang bukan mahram. Ketika dilihat dari titik sebagai wujud toleransi beragama dan menghindari gunjingan yang ditakutkan akan mengarah pada konflik/ pertikaian, peneliti mengarahkan ini dalam tingkatan darurat yang ke dua, yaitu hanya dalam keadaan terdesak ('arûr ât) dibolehkan melakukan tradisi.

Kata Kunci: Perspektif Islam, Padeki Korru, Tradisi Sumba

\section{PENDAHULUAN}

Indonesia dikenal sebagai negara yang plural. Terkenal dengan ragam agama, budaya, suku dan ras. Di dalamnya juga terkenal dengan berbagai macam adat istiadat dan dialek yang berbeda-beda. Indonesia memiliki semboyan berbeda-beda tetapi satu jua. Islam sangat menjaga nilai perbedaan yang ada. Islam disebut sebagai Islam yang kosmopolitan, yaitu budaya yang merangkum dan mengatasi budaya-budaya lokal, regional, dan nasional. Islam mengatasi budaya kesukuan dan budaya-budaya kenasionalan (Kuntowijoyo, 2017). Pluralitas adalah karunia Tuhan. Setiap agama memberikan kontribusi berharga bagi kebudayaan dan peradaban manusia. Meliputi lingkungan spiritual, konsep teologis, dan orientasi nilai (Engineer, 2005). Dengan demikian, hubungan harmonis 
ini dapat terwujud, baik konteks popularitas yang signifikan atau tidak. Toleransi dalam agama Islam sangat diprioritaskan.

Al-Qur'an menyebutkan bahwa Allah melarang untuk bertoleransi dalam masalah akidah dan syariat. Hal itu semata-mata hanya untuk menyatakan bahwa Islam tidak bisa bertoleransi dalam hal akidah, bukan berarti meniadakan nilai toleransi, justru dalam hal ini, Islam membuka ruang untuk saling menghormati atas perbedaan yang ada.

Terkait kebudayaan Indonesia yang kaya akan budaya dengan tradisi khasnya, salah satu adat istiadat yang dianut oleh salah satu budaya yang unik yaitu Padeki Korru. Tradisi ini adalah istilah adat yang sangat populer di Sumba, Provinsi Nusa Tenggara Timur (NTT). Padeki Korru adalah salam dengan cara menyentuhkan hidung dengan hidung (sekedar menyentuh/tidak berlama-lama). Tradisi ini mungkin terasa tabu bagi seseorang yang baru datang ke Sumba. Namun tradisi ini sudah turun temurun dilakukan, sehingga siapa pun tamu yang datang, harus saling mencium hidung terlebih dahulu, sebelum dipersilahkan untuk duduk (Petrus, 2017) . Tradisi ini juga diterapkan di Pulau Sabu Nusa Tenggara Timur (Bangngu \& Pudjibudono, 2019: Claudia et al. , 2020)

Tradisi padeki ini dihadapkan pada masyarakat muslim di Sumba, terutama muallaf yang mengunjungi keluarganya yang nonmuslim, seringkali atau bahkan harus melakukan tradisi Padeki Korru ini. Hal ini akan sulit dihindarkan karena sebelumnya muallaf ini telah melakukannya sehingga tidak dapat menghindari tradisi ini sebab seolah-olah mereka tidak menghargai tradisi keluarga yang non-Muslim.

Perbedaan dalam menyikapi tradisi ini tentunya dapat menimbulkan polemik dalam masyarakat. Apabila tidak dipahami dengan baik adanya budaya tersebut, maka hal ini akan menimbulkan kesalahpahaman bahkan dapat menimbulkan ketegangan dalam masyarakat. Untuk itu, penting sekali penelitian ini dilakukan dan hasilnya untuk dapat dipahami oleh berbagai lapisan masyarakat. Peneliti tertarik melakukan penelitian ini untuk mengetahui praktik tradisi padeki korru masyarakat non Muslim, masyarakat
Muslim dan Muallaf ditinjau dari perspektif hukum Islam.

Penelitian terkait tradisi cium hidung telah banyak ditemukan sebelumnya di daerah lain di Nusa Tenggara Timur dengan nama-nama yang berbeda. Beberapa penelitian terkait telah dilakukan oleh peneliti sebelumnya (Geria, 2014: Simpen et al., 2008: Kleden, 2017: Soeriadiredja, 2013). Apabila penelitian terdahulu lebih membahas pada tradisi secara umum, penelitian ini lebih mendekatkan penelitian pada perspektif hukum Padeki Korru tersebut dari Agama Islam.

Budaya cium hidung ini bertentangan dengan aturan syariat agama Islam yang membatasi perihal melihat dan menyentuh. Meskipun demikian, masyarakat Sumba tetap mempraktikkan tradisi ini karena mereka menganggap bahwa tradisi ini adalah peninggalan moyang yang telah diwariskan turun temurun seperti halnya tradisi lisan yang dipraktikkan di Makasar melalui Parupama (Syamsurijal, 2017). Bermula dari permasalahan yang ada, peneliti sangat tertarik untuk melakukan penelitian budaya ini. Peneliti fokus melakukan penelitian dengan merumuskan masalah, bagaimana pandangan hukum Islam mengenai tradisi adat Padeki Korru dalam maýhâhib alarba'ah? Sesuai rumusan masalah yang ada, tujuan dari penelitian ini adalah untuk mengetahui pandangan hukum Islam mengenai tradisi adat Padeki Korru menurut pandangan hukum Islam dalam maýhâhib al-arba'ah

\section{KAJ IAN TEORI}

Cium hidung adalah salah satu tradisi yang paling terkenal di Sumba. Istilah ini bisa disebut bermacam-macam penyebutannya sesuai daerahnya. Berbagai macam istilah cium hidung di Sumba, penulis lebih memilih istilah Padeki Korru yang berasal dari Kecamatan Loli Kabupaten Sumba Barat. Padeki Korru berasal dari bahasa daerah Sumba Barat. Padeki memiliki arti cium, sedangkan Korru memiliki arti hidung. Sehingga jika digabungkan kedua makna tersebut, Padeki Korru adalah cium hidung.

Filosofi Padeki Korru cium hidung sesungguhnya mempunyai makna dan filosofi 
yang majemuk dan sangat dalam. Hal ini melambangkan relasi kita yang sangat menyatu, akrab, bersahabat, bersaudara, bersolider dan saling mengasihi. Sumba Barat adalah Kabupaten yang berpenduduk dengan multi agama. Islam sebagai agama minoritas. Agama Islam berada di tengah-tengah agama yang mayoritas. Di Sumba Barat ini terkenal dengan agama marapu, dan terbanyak Kristen dan Katolik. Mayoritas masyarakat muslim di Sumba masih minim pemahamannya terhadap agama Islam, wajar apabila mereka sulit untuk tidak membiasakan diri melakukan Padeki Korru. Mereka sangat mempercayai bahwa tradisi ini bukanlah sembarang tradisi, akan tetapi berada pada suasana-suasana tertentu karena berasal dari nenek moyang yang memiliki nilai sakral bersosialisasi pada acara-acara. Saat proses pelaksanaan tradisi perkawinan, pesta pernikahan, Hari raya besar keagamaan, ulang tahun, pesta adat, Kedukaan dan acara perdamaian, dan saat penerimaan tamu-tamu yang dianggap terhormat atau agung yang berasal dari wilayah Sumba sendiri.

'Urf/adat adalah sesuatu yang sudah dikenal bersama dan dijalani oleh masyarakat, baik berupa perbuatan/'amalî ataupun perkataan/ qoulî. Macam-macam dibagi menjadi dua yaitu 'urf 'âm, yaitu 'urf yang berlaku pada seluruh atau mayoritas umat manusia pada masa tertentu dan 'urf khac, yaitu 'urf yang berlaku pada masyarakat atau daerah tertentu pada masa tertentu.

Dilihat dari kesesuaiannya dengan nash dan prinsip syariat, 'urf dibagi menjadi dua macam, yaitu 'urf sahih, yaitu 'urf yang tidak bertentangan dengan nash Al-qur'an atau sunnah dan tidak menghalalkan sesuatu yang haram serta tidak mengharamkan sesuatu yang halal dan 'urf fâsid, yaitu 'urf yang bertentangan dengan nash Al-Quran atau sunah dan menghalalkan sesuatu yang haram serta mengharamkan sesuatu yang halal.

Para ulama sepakat bahwa 'urf fâsid tidak dapat dijadikan acuan dalam penetapan hukum. Sedangkan 'urf sahih, masih diperselisihkan dikalangan ulama. Imam yang empat menjadikan 'urf sahih sebagai acuan penetapan hukum, namun dengan kadar berbeda.

Mayoritas ulama empat maihab memiliki pandangan yang berbeda-beda mengenai bentuk menyapa/menyambut (salam sapa) baik dalam segi bentuk ataupun hukumnya. Tak lepas dari hal menyentuh, tentunya ada batasanbatasan dan bentuk menyentuh menurut pandangan ulama empat mazhab. Yaitu berjabat tangan (mucâfahah), mencium dahi (taqbil al-ra'si wa mâ baina al-'ainain), mencium pipi (taqbil al-khaddi) dan merangkul (mu'ânaqah).

Menurut mazhab Imam Syafi'i bahwa berjabat tangan (mucâfahah) ini sangat disunahkan bagi dua orang laki-laki atau dua orang perempuan yang baru datang, ketika bepergian atau ketika bertemu di jalan. Karena dengan mucâfahah, dosanya diampuni (Sholih, 2016). Mazhab Imam Syafi'i, Imam \$anafi dan Imam Maliki, bahwa mucâfahah ini hanya tertentu dilakukan sesama mahram (laki-laki dan lakilaki/ perempuan dan perempuan).

Mencium dahi (taqbil al-ra'si wa mâ baina al'ainain) menurut mazhab Imam Syafi'i membolehkan penyambutan kepada seseorang yang baru datang dari perjalanan atau baru mau bepergian dengan cara mencium kepala atau mencium dahinya (An-Nawawiy, 1991). Sedangkan menurut maihab Imam Hanafi, kebolehan mencium kepala hanya dari anak kepada orang tuanya dengan dasar kasih sayang. Sedangkan mencium dahi hanya tertentu kepada sesama saudara lakilaki ('Aliy, 2015). Di dalam mazhab Imam Maliki tidak dijumpai pembahasan mengenai mencium kepala dan dahi. Sedangkan mazhab Imam Hanbali, mencium kepala hanya boleh dilakukan oleh dua orang muslim laki-laki atau perempuan yang dipandang karena ilmu dan agamnya

Mencium pipi (taqbil al-khaddi) dalam mazhab Imam Syafi'i, mencium pipi hanya boleh dilakukan pada anak bayi serta bagian anggota tubuh lainnya dengan alasan kasih sayang. Baik bayi sendiri atau milik orang lain (An-Nawawiy, 1991). Sedangkan di dalam mazhab Imam Hanafi kebolehan mencium pipi tertentu menciumnya orang tua pada anaknya karena kasih sayang dan sesama saudara kandung baik saudara laki-laki dan perempuan atau saudara laki-laki dan laki-laki ('Aliy, 2015). Adapun 
di dalam mazhab Imam Maliki dan Imam Hanbali tidak menjelaskan tentang mencium pipi sama sekali.

Merangkul (mu'ânaqah) Di dalam mazhab Imam Syafi'i mengatakan, mu'ânaqah hukumnya makruh, baik mu'ânaqah dengan kepala atau dengan wajah (Asy-Syafi'i>y, 2000). Mayoritas maihab Imam Maliki menghukumi makruh melakukan mu'ânaqah tanpa alasan yang jelas. Menurut mazhab Imam \$anafi, mu'ânaqah hukumnya makruh baik melakukan mu'ânaqah dalam rangka menyambut kedatangan atau ketika bertemu di jalan (Al-Mishriy, 1997). Di dalam mazhab Imam Hanbali membolehkan melakukan mu'ânaqah dengan orang yang baru datang dari bepergian atau melakukan mu'ânaqah dengan orang yang ahli agama dan ilmunya.

Agama Islam mengenal istilah hubungan mahram. Dalam pembahasan ini diurai masalah mahram menurut empat mazhab yang mempunyai pandangan yang berbeda-beda. Empat mazhab sepakat, hubungan mahram disebabkan oleh tiga, yaitu hubungan nasab, rada dan hubungan kemertuaan (mucâharah).

Pengadopsian adat-istiadat atau tradisi masyarakat Arab ke dalam hukum Islam mengambil tiga pola, pertama syariat mengambil sebagian tradisi itu dan membuang sebagian lainnya. Kedua, Islam mengambil sebagian dan membuang sebagian lainnya dengan penambahan atau pengurangan di dalam beberapa sisi. Ketiga, Islam mengambilnya secara utuh tanpa adanya perubahan bentuk dan identitasnya. Akan tetapi dari tiga pola ini, Islam tidak mengubah hukumhukum inti, konsep-konsep dasar apalagi nac-nac qam'î. Abdul Karim Zaidan menganalisis dari sudut yang berbeda terkait tiga pola penyerapan syariat terhadap budaya masyarakat Arab. Pola pertama, Nabi Saw banyak mengadopsi budaya-budaya Arab yang bernilai positif sementara kebiasaan-kebiasaan negatif ditinggalkan. Kedua hakikat penerapan adat sebenarnya merupakan pemberlakuan dalildalil syariat itu sendiri. Artinya, bila adat tersebut dijadikan acuan, maka sejatinya hukum yang diancang adalah hukum yang didasarkan dengan dalil nac (selain al-Qur'an dan al-Hadis), seperti ijma', istihsân, maslahah mursalah, maupun saddu al-zari'ah. Nahe'i, I., and Wawan Djuandi,
Revitalisasi Ushul Fikih Dalam Proses Istinbath Hukum Islam (Situbondo: Ibrahimy Press, 2010), 127-51.

'Urf bisa dijadikan sebagai pijakan hukum bila memenuhi empat kriteria. Pertama 'urf tersebut berlaku konstan (bersifat umum dan sulit berubah) dan menyeluruh atau minimal dilakukan oleh kalangan mayoritas. Kedua, 'urf s udah terbentuk sebelum atau bersamaan dengan masa penggunaannya/ kebiasaan yang baru muncul tidak diperhitungkan. Ketiga, Tidak terdapat ucapan atau pekerjan yang nyata-nyata bertentangan dengan nilai-nilai substansial 'urf. ke empat, 'urf tidak bertentangan dengan syariah. Artinya 'urf tersebut berupa 'urf sahih yaitu tidak sampai menganulir seluruh aspek substansial nas sebab, bila isi bertentangan dengan nas sebab terdapat beberapa nas yang tidak tereliminasi.

Islam mengenal kondisi darurat. Pengertian darurat adalah kondisi mendesak untuk dilakukan yang mana ketika ditinggalkan akan membinasakan diri kita sendiri. Ibramih, M. M. al-Haririy., Daar Imaar, n.d., 107. Apabila mafsadah dan maslahah bertentangan sebaiknya yang diutamakan adalah menolak mafsadah. Sekalipun ketika mendahulukan hal tersebut menyebabkan hilangnya sebagian maslahah.

\section{METODE PENELITIAN}

Penelitian ini adalah penelitian Etnografi tentang tradisi adat Padeki Korru di Sumba. Penelitian ini menggunakan pendekatan kualitatif yaitu penelitian yang lebih menekankan pada realitas sosial, baik dengan melakukan wawancara terhadap beberapa pihak yang terkait dengan tradisi ini serta dokumentasi/ pengambilan gambar secara langsung. Mengenai teori hukum Islam akan disesuaikan terhadap tradisi ini, sehingga menghasilkan keputusan akhir mengenai batasan-batasannya. Penelitian ini dilakukan di Sumba Barat Provinsi Nusa Tenggara Timur. Sumber informasi/narasumber pada penelitian ini adalah warga muslim, warga nonMuslim, dan muallaf yang mempraktikkan tradisi tersebut.

Subyek dalam penelitian ini adalah masyarakat Sumba Tengah dan Sumba Barat Daya 
Prov. Nusa Tenggara Timur. Pengumpulan data dilakukan dengan melakukan wawancara langsung secara mendalam pada warga yang mempraktikkan adat Padeki Korru ini. Selain melakukan wawancara mendalam, peneliti juga mengamati langsung praktik tradisi ini secara instens mulai dari Oktober 2019 sampai dengan Pebruari 2021.

\section{TEMUAN DAN PEMBAHASAN}

A. Temuan

Praktik Padeki Korru oleh Ibu AYJ penduduk Sumba yang beragama Islam, Desa Waikelo, Kecamatan Tambolaka, Kabupaten Sumba Barat Daya. "Istilah daerah dari daerah saya Waikelo ini disebut Pangu'ju Urru, Pangu'ju Urru ini merupakan sebuah tradisi, baik laki-laki dengan laki-laki, perempuan dengan perempuan, atau bahkan perempuan dengan laki-laki. Biasanya Pangu'ju Urru ini dilakukan ketika acara-acara besar, seperti lebaran, perkumpulan keluarga. Praktek yang dilakukan biasanya dengan sekedar menyentuhkan hidung saja, sekitar 2 sampai 3 detik. Saya pernah melakukan Pangu'ju Urru dengan orang yang bukan mahram saya. Akan tetapi semenjak saya paham, bahwa melanggar syariat ya sudah saya hanya lakukan dengan orang yang mahram saja, seperti kakak saya, adik, orang tua. Meskipun tidak bisa dipungkiri bahwa orang-orang di Sumba ini sudah menganggap tradisi sehingga mereka tanpa menganggap mahram atau tidak. Ketika darurat, artinya penyambutannya mendesak mungkin saya terpaksa melakukan, karena menghargai keadaan agama Islam yang minoritas. Kalau neneknenek yang sudah sepuh, saya sering melakukan ini, karena mereka sudah tidak memiliki syahwat lagi. Saya punya keluarga yang non-muslim, saya lakukan saja tapi tetap pada memperhatikan mahram, kalau bukan keluarga, biasanya saya hanya berjabat tangan saja. Tradisi ini sudah mendarah daging" menurut AYJ.

Praktik serupa dilakukan oleh Bp. CS, penduduk Sumba yang beragama Islam, Kecamatan Kota Waikabubak, Kabupaten Sumba Barat. "Saya lahirnya di Sumba, jadi anggaplah saya orang Sumba, walaupun notabenenya pendatang/campuran. Padeki Korru ini sudah mentradisi, mereka lebih memilih Padeki Korru daripada berjabat tangan. Saya sering melakukan Padeki Korru ini pada sesama saudara yang semahram saja. Walaupun dulu saya sering melakukan sama yang bukan mahram, akan tetapi karena sudah paham, ya saya tidak melakukan. Biasa kalau dalam keadaan darurat terpaksa saya lakukan, kita kembalikan ke adat lagi, namanya juga salam yang paling bagus menurut kita yaitu Padeki Korru ini. Kita menghargai tradisi mereka karena tau diri mereka yang mayoritas juga".

Praktik serupa juga dilakukan oleh Bp. MUH, beragama Islam, penduduk asli Sumba yang berasal dari Desa Waikelo, Kecamatan Tambolaka, Kabupaten Sumba Barat Daya. "Istilah cium hidung di daerah saya yaitu Panagu'ju Urru, pangu'ju itu cium dan urru itu hidung. Tradisi ini sering dilakukan baik laki-laki dengan laki-laki atau sesama perempuan atau laki-laki dan perempuan. Orang-orang kebanyakan lebih memilih Pangu'ju Urru daripada berjabat tangan, karena ini lebih dekat keakrabannya. Menurut saya memang sangat menyalahi syariat Islam, akan tetapi itu sudah menjadi tugas kita sebagai penyuluh terutama dari Waikelo ini. Saya sering melakukan Pangu'ju Urru ini dulu, tapi sekarang saya hanya melakukan pada yang mahram saja. Ketika dalam keadaan darurat misalnya, kalau ada penyambutan yang seketika dengan Pangu'ju Urru maka saya ada dua kemungkinan mencari solusi lain seperti langsung berjabat tangan, kalau tidak terpaksa melakukan Pangu'ju Urru ini. Orang-orang lebih memperhatikan toleransi sesama umat atau sesama muslim, agama Islam di Sumba ini minoritas, sehingga mereka tetap melakukan tradisi ini karena toleransi antar agama tanpa memandang ini mahram atau tidak. Alasannya ini sudah membudaya" menurut Pak MUH.

Praktik serupa dilakukan oleh Bp. IH, beragama Islam penduduk asli Sumba yang berasal dari Kecamatan Kota Waikabubak, Kabupaten Sumba Barat. "Pangu'ju Urru namanya, caranya dengan cara saling menyenggolkan sesama hidung dan hanya sekedar menyentuhkan saja". Saya punya keluarga yang 
non-muslim, jangankan ke yang non-muslim dulu, keluarga saya saja yang muslim tanpa memperhatikan mahram atau tidak, alasannya karena ini sudah biasa. Saya sering lakukan ini pada teman, keluarga apa lagi. Tujuan utama ini supaya lebih dekat, dan ini ciri khas kita, seringnya mereka memakai jabat tangan, beda dengan di Sumba yaitu dengan Pangu'ju Urru ini".

Praktik serupa juga dilakukan oleh Ibu SNA, beragama Islam, penduduk asli Sumba yang berasal dari kelurahan Komerda, Kota Waikabubak, Kabupaten Sumba Barat. "Kalau istilah daerah saya tidak tahu, tapi tentang cium hidung ini sangat populer. Orang-orang sering saling cium hidung dengan cara pegang pundak lalu cium sudah. Saya sering melakukan ini juga, lebihlebih yang beda agama tanpa memperhatikan mahram lagi kalau sesama muslim saya jarang melakukan ini, karena komplek saya kebanyakan non-muslim. Tradisi ini dilakukan ketika ada acara, seperti kematian, pernikahan, dan lama tidak ketemu. Tradisi ini sudah dari dulu, dari nenek moyang kita. Apalagi ketika dalam keadaan mendesak pasti saya akan lakukan, karena takut ada omongan, sombonglah, lupa dirilah dan lain sebagainya".

Praktik serupa dilakukan oleh Ibu ZAS beragama Islam, penduduk asli Sumba yang berasal dari Kelurahan Komerda, Kota Waikabubak, Kabupaten Sumba Barat. "Istilah bahasa Indonesianya cium hidung. Disebut cium Sumba populernya. Saya pernah dengar istilahnya dengan sebutan Pangu'ju. Saya sering melakukan cium hidung ini, biasanya saya lakukan tradisi ini dengan orang yang saya kenal. Kalau yang tidak saya kenal ya hanya berjabat tangan. Memang dalam Islam membatasi mahram atau tidak. Akan tetapi ketika sudah dihadapkan tradisi ini jadi tidak bisa dihilangkan dan tetap dilakukan tanpa lihat mahram atau tidak. Saya sering melakukan ini sama keluarga yang non-muslim baik tetangga atau keluarga muslim lebih-lebih ketika Natal. Ini sudah membudaya dari nenek moyang kita, setiap ketemu di jalan pasti cium hidung. Apalagi ada kematian orang non-muslim itu mereka sambut dengan cium hidung dan tidak bisa dihindari inilah salah satu bentuk toleransi beragama kita".
Praktik serupa juga dilakukan oleh Ibu A beragama Islam, penduduk asli Sumba yang berasal dari Waitabula, Kabupaten Sumba Barat Daya. "Kalau daerah saya bilang Ngu'ju, caranya, biasanya kalau pada laki-laki masih berpelukan lalu Ngu'ju, kalau ibu-ibu masih cium pipi baru Ngu'ju. Dalam keluarga muslim, saya sering melakukan ini, baik pada keluarga atau tetangga, teman tanpa memandang mahram karena dilihat dari adat/tradisi. Kalau sama non-muslim saya sering sama perempuan saja, kalau laki-laki tidak pernah. Saya suka Ngu'ju ini karena ini tali persaudaraannya sangat terasa, bentuk kasih sayang, dan mungkin ini adalah adat dan kebiasaan yang sudah dari nenek moyang kita".

Praktik serupa juga dilakukan oleh Ibu $\mathrm{F}$ beragama Islam, penduduk asli Sumba yang berasal dari kelurahan Wailiang, Kota Waikabubak, Kabupaten Sumba Barat. "Cium Sumba dari daerah saya sering disebut Pang'ju Urru. Salam Sumba ini sering dilakukan di Sumba. Sering ketika baru berjumpa karena sudah sekian lama tidak berjumpa. Saya sering melakukan ini, kalau tidak dilakukan biasanya dibilang sombonglah, karena sudah lama di Jawa lupalah sama adat. Karena dengan Pangu'ju Urru ini kekeluargaan lebih dekat. Sering juga sama bukan mahram karena sudah mentradisi. Tapi karena sudah sedikit paham agama, jadinya sedikit membatasi. Kalau mendesak, sebenarnya ingin menolak, tapi karena tradisi ya sudah hanya hidung sama hidung saya lakukan. Saya juga tidak tahu bagaimana cara menghilangkannya, tahu sendirikan nanti ada omongan sombonglah, kacang lupa kulitlah. Ini sudah tradisi.

Praktik tradisi yang dilakukan oleh masyarakat yang beragama Islam di Sumba yang telah diteliti oleh peneliti adalah tradisi Padeki Korru ini sering dilakukan terhadap orang yang bukan mahramnya. Alasannya baik karena keadaan mendesak/sulit dihindari atau karena tradisi yang sudah populer sehingga sekalipun bukan mahram tetap dilakukan.

Praktik cium hidung yang dilakukan oleh Ibu YVTB, beragama Katolik, penduduk asli 
Sumba yang berasal dari Kecamatan Loli, Kabupaten Sumba Barat bahwa tradisi Padeki Korru ini sering ia lakukan dengan para penduduk Sumba yang beragama Islam. "Saya pernah melakukan Padeki Korru dengan orang muslim bahkan sering. Di dalam keluarga saya itu multi agamanya, termasuk Islam. Di Sumba ini sangat tinggi toleransi agamanya, sehingga tidak memperhatikan pembeda lagi atau kalau dalam muslim kan memperhatikan mahram atau tidak. Dan ini hanya bentuk toleransi saja. Saya sering melakukan Padeki Korru ini, bahkan sama orang muslim juga yang bukan keluarga. Kadang ketika Natal, kadang juga ketika Idul Fitri, akan tetapi dalam tanda kutip, saya lakukan Padeki Korru ini sama muslim yang sudah berdomisili di Sumba. Fungsi utamanya yaitu mempererat tali persaudaraan. Padeki Korru sering kali dilakukan tanpa dibeda-bedakan kepada siapa, sekalipun kepada orang muslim, karena bentuk toleransi orang muslim yang menghargai/menerima tradisi kita".

Praktik serupa juga dilakukan oleh Bp. DB beragama Katolik, penduduk asli Sumba yang berasal dari Kecamatan Tana Righu, Kabupaten Sumba Barat Daya bahwa tradisi Padeki Korru ini sering ia lakukan dengan para penduduk Sumba yang beragama Islam. "Kalau dari Kecamatan Tana Righu, Padeki Korru itu disebut Padeki Korruna. Saya pernah melakukan Padeki Korruna dengan orang muslim tanpa memandang laki-laki atau perempuan dan berulang kali. Sama keluarga yang muslim atau tetangga, karena ini bentuk toleransi dari nenek moyang kita. Dan ini juga ciri khas kita yang tidak bisa dihilangkan. Fungsi tradisi Padeki Korruna yaitu saling mengenal, menghormati kepada orang tua kita, meredam konflik, kalau ada yang mau damai lalu tidak mau melakukan tradisi ini berarti dia belum memaafkan. Bentuk toleransi ini dari orang muslim yang menerima tradisi Padeki Korru ini".

Praktik serupa dilakukan oleh Bp. IUP, beragama Katolik, penduduk asli Sumba yang berasal dari Kecamatan Tana Righu, Kabupaten Sumba Barat Daya bahwa tradisi Padeki Korru ini sering ia lakukan dengan para penduduk Sumba yang beragama Islam. "Istilah daerahnya saya yaitu Padeki Korru. Saya sering melakukan Padeki Korru sama keluarga sendiri, saya pernah melakukan Padeki Korru sama orang yang beragama muslim bahkan sering. Intinya Padeki Korru di Sumba ini sudah mentradisi dan sulit untuk dihilangkan. Ini budaya kita. Fungsi utamanya biasanya untuk menguatkan tali persaudaraan, meredam konflik dan berdamai menggunakan tardisi ini sebagi tanda sudah akur dan damai. Serta melambangkan silaturahmi yang sangat baik. Orang muslim tetap mengakui dan mempraktekkan tradisi ini, karena mereka mentolerir tradisi yang membudaya ini di Sumba".

Praktik Padeki Korru yang dilakukan oleh penduduk asli Sumba yang beragama nonmuslim terhadap masyarakat yang muslim yang telah diteliti oleh peneliti adalah mereka sering melakukan tradisi Padeki Korru ini terhadap masyarakat yang muslim tanpa melihat hubungan mahramnya.

Praktik Padeki Korru yang dilakukan oleh ibu FS beragama Islam sekaligus sebagai seorang muallaf penduduk asli Sumba yang berasal dari Kecamatan Kota Waikabubak, Kabupaten Sumba Barat. Menurut beliau Padeki Korru ini merupakan bentuk toleransi beragama. Terutama di dalam menghadapi keluarganya yang non-muslim. Menurut ibu FS Padeki Korru ini tidak semudah itu kita meniadakannya alasan singkatnya karena Padeki Korru ini merupakan tradisi dari nenek moyang kita sejak dahulu kala. "Saya orang Tana Righu, asli orang daerah Sumba. Saya seorang muallaf. Istilah cium Sumba dari daerahnya saya disebut padekkina. Cara melakukan ini biasanya dua orang saling memegang tengkuk kepala lalu saling mencium hidung. Apalagi ketika saya datang ke keluarga saya yang non-muslim pasti saya melakukan padekina ini. Ini sudah adat, tidak bisa dihilangkan lagi, tidak melihat mahram atau tidak lagi, ini namanya adat. Kalau tidak dilakukan, terus tidak mau, maka mereka akan menilai miring, omongan-omongan tidak enak akan muncul. Saya dari kecil seorang Katolik, ketika sekarang bersilaturahmi dengan keluarga yang non-Muslim, maka saya harus memakai itu. Sulit dihilangkan. Ini sudah terbiasa. Ketika saya seorang muslim seperti sekarang saya sering ikut pengajian-pengajian, kita sering lakukan padeki ini dan orang-orang Jawa yang baru satu 
tahun menetap saja sudah mengikuti tradisi padeki ini, apalagi yang sudah bertahun-tahun. Ini adalah adat sulit sekali kalau mau kasih hilang kebiasaan ini".

Praktik Padeki Korru yang dilakukan oleh seorang muallaf, penduduk asli daerah Sumba terhadap masyarakat Sumba, baik yang muslim atau non-muslim yang diteliti peneliti adalah praktik Padeki Korru ini tetap dilakukan baik dilakukan kepada sesama muslim atau nonmuslim, alasan dasarnya adalah tradisi yang sudah tidak bisa dihilangkan. Berdasarkan pengamatan, dalam kaitan tradisi ini tetap saja dilakukan tanpa memandang mahram karena ada dua faktor umumnya, yaitu Menjaga hubungan sosial sebagai wujud toleransi beragama dan Kelompok minoritas terpaksa harus mengikuti kelompok mayoritas. Masyarakat muslim di Sumba yang minoritas harus mengikuti masyarakat non-muslim yang mayoritas demi menjaga hubungan baik. Menurut narasumber FS, seorang muallaf berpendapat bahwa Karena tradisi Padeki Korru tidak bisa dihilangkan dan tetap dilakukan, baik pada saudara sesama muslim atau non-muslim tanpa memandang mahram untuk menjaga nilai toleransi.

\section{B. Pembahasan}

Praktik Padeki Korru yang dilakukan oleh seorang muallaf, penduduk asli daerah Sumba terhadap masyarakat Sumba, baik yang muslim atau non-muslim yang diteliti peneliti adalah praktik Padeki Korru ini tetap dilakukan baik dilakukan kepada sesama muslim atau nonmuslim, alasan dasarnya adalah tradisi yang sudah tidak bisa dihilangkan. Berdasarkan pengamatan, dalam kaitan tradisi ini tetap saja dilakukan tanpa memandang mahram karena ada dua faktor umumnya, yaitu menjaga hubungan sosial sebagai wujud toleransi beragama dan kelompok minoritas terpaksa harus mengikuti kelompok mayoritas. Masyarakat muslim di Sumba yang minoritas harus mengikuti masyarakat non-muslim yang mayoritas demi menjaga hubungan baik. Menurut narasumber FS, seorang muallaf berpendapat bahwa karena tradisi Padeki Korru tidak bisa dihilangkan dan tetap dilakukan, baik pada saudara sesama muslim atau non-muslim tanpa memandang mahram untuk menjaga nilai toleransi.

Interaksi tidak terlepas di dalam kehidupan sosial. Saling membutuhkan baik dalam lingkup keluarga ataupun masyarakat. Islam memiliki batasan-batasan melihat ataupun menyentuh dalam berinteraksi. Ada batasan yang boleh disentuh dan dilihat, ada juga batasan yang boleh dilihat tapi tidak boleh disentuh. Islam mengenal istilah mahram yang mengimplikasikan untuk tidak boleh menikah. Selain menghalangi pernikahan, adanya hubungan mahram, empat ma¿hab berbeda dalam hal kebolehan menyentuh dan khalwat. Ma ¿hab Imam Syafi'i dan Hanafi membolehkan menyentuh dan khalwat (al-Mishri, 2013). Mazhab Imam Syafi'i hanya menjelaskan menyentuh tidak akan membatalkan wudhu, sedangkan mazhab Imam Hanafi menjelaskan kebolehan menyentuh saja tanpa menyinggung batal dan tidaknya wudhu. Di dalam mazhab Imam Maliki hanya menjelaskan bahwa menyentuh sesama mahram akan membatalkan wudhu ketika ia merasa nikmat sebab menyentuh. Sedangkan di dalam maihab Imam Hanbali tidak dijumpai penjelasan mengenai kebolehan menyentuh. Pembahasan tentang menyentuh perspektif empat mazhab yang dikaitkan dengan bentukbentuk salam sapa dibagi dalam empat bagian. Pertama, mucâfahah (berjabat tangan). Kedua, taqbil al-ra'si wa m baina 'ainain (mencium kepala dan dahi). Ketiga, taqbil al-khaddî (mencium pipi). Keempat, mu'ânaqah (merangkul). Dari empat bentuk menyapa ini, empat mazhab sepakat batasan menyentuh hanya boleh dilakukan kepada sesama mahram. Kecuali dalam hal mucâfahah maihab Hanafi membolehkan mucâfahah dengan laki-laki/perempuan tua renta tanpa memandang batasan mahram dengan alasan sudah tidak disyahwati. Di dalam pembahasan ini, peneliti lebih memilih taqbil alkhaddî (mencium pipi) dan mu'ânaqah (merangkul/menyentuhkan leher) yang lebih mendekati dengan tradisi Padeki Korru. Alasan taqbil alkhaddî (mencium pipi) mendekati Padeki Korru, yang pertama, berada dibagian wajah, dan mendekati hidung. Alasan mu'ânaqah (merangkul/ 
menyentuhkan leher) karena leher mendekati wajah, serta ketika melakukannya, wajah mengikuti pergerakannya dan saling berhadapan. Sehingg ketentuan Padeki Korru ini sama dengan ketentuan taqbil al-khaddî (mencium pipi) yaitu hanya kepada sesama mahram lebih spesifiknya hanya kepada orang tua ke anaknya atau saudara kepada saudara kandungnya saja dan mu'ânaqah (merangkul/menyentuhkan leher), hanya kepada sesama mahram. Padeki Korru merupakan tradisi yang dikategorikan pada 'urf yang fâsid karena tradisi tersebut keluar dari ketentuan syariat Islam yaitu melakukan cium hidung tanpa memandang mahram. Berdasarkan pengertian bahwa 'urf fâsid adalah kebiasaan yang sudah sering dilakukan akan tetapi keluar dari batasan/ ketentuan syariat Islam.

Berdasarkan hasil wawancara peneliti, Padeki Korru ini sangat sering dilakukan tanpa memandang mahram dengan alasan yang signifikan, yaitu takut akan terjadinya gunjingan ketika berusaha menghindarinya sehingga mengarah pada konflik. Alasan lainnya, jika dalam keadaan sulit untuk dihindari sebab sambutan yang spontan maka dengan terpaksa tradisi Padeki Korru ini tetap dilakukan tanpa memandang mahram karena menjaga toleransi beragama di Sumba. Melihat satu kondisi terpaksa/mendesak dengan alasan di atas, peneliti mengarahkan Padeki Korru kepada keadaan darurat. Berdasarkan pengertian bahwa darurat adalah kondisi mendesak untuk dilakukan yang mana ketika ditinggalkan akan membinasakan diri kita sendiri. Berdasarkan

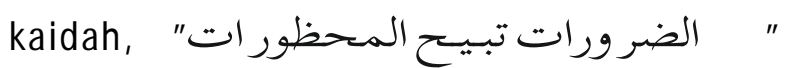
bahwa dalam keadaan darurat membolehkan hal-hal yang haram untuk di lakukan, macam darurat dibagi menjadi tiga bagian (Azaam, 2005). Pembagian pertama, bahwa darurat itu membolehkan apa yang diharamkan oleh Allah, dan tidak menghilangkan tanggungan. Kedua, boleh melakukan sesuatu yang dilarang tanpa mengubah hukumnya. Ketiga, tidak boleh sama sekali melakukan yang dilarang dalam keadaan apapun. Ketika melihat kondisi di Sumba yang terkenal dengan Islam minoritasnya beserta melihat implikasi ketika meninggalkan adat tradisi Padeki Korru, peneliti mengarahkan bentuk darurat melakukan
Padeki Korru ini pada bentuk yang kedua, artinya boleh melakukan tradisi ini hanya dalam keadaan terpaksa tanpa menghilangkan hukum asal larangan menyentuh kepada yang bukan mahram. Alasan spesifiknya, pertama tradisi ini sebagai bentuk toleransi bagi masyarakat Islam minoritas di Sumba.

Sebagai contoh toleransi mereka dalam hal sambutan yang spontan cara Padeki Korru. Dari sini sulit untuk menghindar/ataupun menolak. Tradisi ini dinilai sebagai bentuk toleransi umat beragama di Sumba. Alasan spesifik lainnya, jika tidak melakukan tradisi Padeki Korru ini, maka akan medapatkan gunjingan, hinaan, mendapatkan pembicaraan-pembicaraan yang tidak indah didengar karena dianggap telah mengasingkan diri dari tradisi nenek moyang yang sudah mentradisi. Kesimpulannya, kebolehan melakukan tradisi ini hanya dalam keadaan terpaksa yang mana tidak bisa dialihkan kepada perbuatan lainnya, jika tidak dalam keadaan terpaksa maka tidak boleh dilakukan. Perbandingannya, seperti kebolehan seorang dokter melihat bagian yang harus ditutup menurut syariat bagi pasien. Apabila dikaitkan dengan kondisi ini, syariat mengutamakan menjaga jiwa (hifz al-nafs) daripada menjaga agama (hifz al-dîn). Dengan menjaga jiwanya, maka dia akan leluasa untuk beribadah dan menjaga nilai-nilai dalam agamanya. Sama halnya dengan Padeki Korru, kebolehan mencium hidung tanpa memandang mahram sebagai wujud toleransi beragama dan menghindar gunjingan yang mengarah pada konflik. Mendahului hifz al-nafs daripada hifz al-dîn, maslahahnya lebih besar, pertama mempertahankan nilai agama Islam di daerah minoritas yang mungkin secara akan menjadi agama Islam mayoritas di Sumba (Azaam, 2005). Jika tradisi Padeki Korru dikaitkan dalam pembahasan maslahah mursalah (maslahah al-hajiyyah, maslahah al-tahsiniyyah, maslahah al-darûriyyah) sebagai wujud toleransi antar umat, Padeki Korru ini masuk di dalam tingkatan darûriyyah, yaitu tingkatan kebutuhan yang harus ada. Jika tidak maka keselamatan manusia akan terancam dengan memandang lima hal pokok (hifz al-nafs, hifz al-dîn, hifz al-'aql, hifz al-nasl, hifz al-mâl). Dengan melakukan 
tradisi Padeki Korru ini maka ada banyak maslahah yang tercapai Rahman, (2016). Pertama, sebagai wujud toleransi mayoritas non-muslim di Sumba terhadap minoritas Islam. Kedua, dengan toleransi tradisi Padeki Korru ini maka minoritas muslim di Sumba dapat terus eksis untuk mempertahankan nilai keislamannya sehingga Islam berkembang. Sama halnya orang sakit parah jika salat maka dia akan celaka, sehingga lebih baik ia meninggalkan shalat untuk menjaga dirinya, artinya mendahulukan hifz al-nafs daripada hifz al-dîn, karena jika dilihat, maslahahnya lebih besar, dengan menjaga kesehatan kita, salat akan bisa dilakukan setelah sembuh. Sama seperti Padeki Korru dalam hal menjaga nilai toleransi antar ummat, tetap melakukan tanpa memandang mahram. Selain itu juga untuk menghindari gunjingan yang mengarahkan pada konflik. Mendahulukan hifz al-nafs daripada hifz al-dîn.

\section{PENUTUP}

\section{A. Simpulan}

Menurut pandangan maýhâhib al-arba'ah bentuk menyentuh yang dikaitkan dalam salam sapa dibagi menjadi empat macam. Ada taqbil al-ra'si wa mâ baina al-'ainain (mencium kepala dan dahi), taqbil al-khaddî (mencium pipi), mu' ânaqah (merangkul/saling menyentuhkan leher) dan mucâfahah (berjabat tangan). Tradisi Padeki Korru ini merupakan 'urf yang fâsid karena keluar dari ketentuan syariat dalam hal larangan menyentuh kepada yang bukan mahram.

Akan tetapi berdasarkan empat salam sapa yang ada, dilihat dari titik sebagai wujud toleransi beragama dan menghindari gunjingan yang ditakutkan akan mengarah pada konflik/ pertikaian, Padeki Korru ini mengarah dalam tingkatan darurat yang ke dua, yaitu ketika dalam keadaan terdesak (darûrât) dibolehkan melakukan tradisi ini.

Sebisa mungkin seorang muslim yang sudah mengerti akan batasan syariat dalam hal menyentuh sebaiknya ia harus benar-benar membatasinya jika tidak berada dalam keadaan yang benar-benar mendesak. Ketika syariat memberikan sedikit kelonggaran, bukan berarti hal ini menjadi alasan untuk melakukan kebebasan secara terus menerus. Bagi yang sudah memahami untuk bertahap memberikan penyuluhan mengenai batasan menyentuh menurut syariat kepada masyarakat umumnya terutama yang sangat awam tentang agama.

\section{B. Rekomendasi}

Penelitian ini mengenai adat saling menyentuhkan hidung perspektif hukum Islam ini hanya dilakukan di sebagian kecil daerah Sumba, khususnya Sumba Barat dan Sumba Barat Daya. Penelitian selanjutnya dapat dilakukan pada masyarakat Muslim lain di Kabupaten berbeda di Provinsi Nusa Tenggara Timur terutama di Kabupaten Sabu Raijua karena penelitian perspektif budaya terkait tradisi saling menyentuhkan hidung telah banyak dilakukan di Kabupaten tersebut tetapi belum diketahui peneliti yang mengkhususkan pada penduduk muslim. $[\alpha]$

\section{DAFTAR PUSTAKA}

'Aliy, Abu bakar bin. 2015. Al-Jauharoh An-Nairoh. Beirut: Maktabah Syamela (Al-Mathba'ah Al-khoiriyyah). http:// pmhbuinbandung999. blogspot.com/2017/08/ membahas-kitab-figh_7.html?m=1.

Al-Haririy, Ibramih Muhammad Mahmud. 1998. Daar Imaar. Syuria.

al-Mishri, S. 2013. Hasyiyah Al-Jamal Syarah Al-Manhaj. 8th ed. Beirut: Darul Kutub Islamiyah.

Al-Mishriy, Zainuddin Bin Ibrahim. 1997. Al-Bahru Ar-Raaiq. Beirut: Dar al-KOTOB al-ILMIYAH. http:// nahdlatululama.id/ blog/ 2019/ 03/ 18/ kitab-al-bahrur-roiq-karangan-syekh-ibnu-nujaim/ .

An-Nawawiy, Abu Zakaria Muhyiddin Syarif. 1991. Roudh At-Thalibin Wa Umdah Al-Mufthin. Beirut: Maktabah Syamel (Maktabah Islami).

Asy-Syafi'i>y, Syamsuddin Muhammad Bin Al-Khootib Asy-Syarbini. 2000. Mughn Al-Muhtaaj Ila Ma'rifat Ma'aniy Al-Faazhi Al-Minhaaj. Beirut: Maktabah Syamela (Daar Al-kutub Al-'ilmiyah). 
Azaam, Abdul 'Aziz Muhammad. 2005. Qowaid Fiqhiyah. Jakarta: Dar Al-hadits.

Bangngu, Harini Edgina Mariana, and Jatie K. Pudjibudono. 2019. "Henge'dho Seni Mengungkapkan Isi Hati". Intuisi 11 (3): 193-201.

Claudia, Benedikta Yovi, Rustono Farady Marta, and Ignatius Cahyanto. 2020. "City Branding of East Nusa Tenggara through the Video Narration Exotism of Sabu Island". Jurnal IImu Komunikasi 18 (2): 16980. Engineer, A. A. 2005. Islam Masa Kini. Yogyakarta: Forstudia.

Geria, I. M. 2014. "Kampung, Kearifan Ekologis Megalitik Rindi Praiyawang Sumba Timur". Forum Arkeologi 27 (2): 99-108.

Kleden, Doni. 2017. "Belis Dan Harga Seorang Perempuan Sumba (Perkawinan Adat Suku Wewena, Sumba Barat Daya NTT)". Jurnal Studi Budaya Nusantara 1 (1): 24-35. https:/ / jsbn.ub.ac. id/ index. php/ sbn/ article/ view/3.

Kuntowijoyo. 2017. Dinamika Sejarah Umat Islam Indonesia. Yogyakarta: Penerbit IRCiSoD.

Nahe'i, Imam, and Wawan Djuandi. 2010. Revitalisasi Ushul Fikih Dalam Proses Istinbath Hukum Islam. Situbondo: Ibrahimy Press.

Petrus, Ananias. 2017. "Tradisi Cium Hidung, Cara Masyarakat Sumba Sambut Presiden Jokowi". Merdeka.Com. 2017. https:/ / www.merdeka.com/ peristiwa/ tradisi-cium-hidung-cara-masyarakat-sumba-sambutpresiden-jokowi.html.

Rahman, Z. 2016. Fikih Nusantara Dan Sistem Hukum Nasional. Yogyakarta: Pustaka Pelajar.

Sholih, Muhammad Bin. 2016. Syarhu Riyadh As-Sholihin. Jakarta: Maktabah Syamela. (Darul Wathon li annasyr).

Simpen, I. W. A. M. Mbete, I. M. Suastra, and I. W. Pastika. 2008. "Kesatuan Berbahasa Pada Penurut Bahasa Kambera Di Sumba Timur". E-J ournal of Linguistics 2 (1): 1- 15. https:// ocs. unud.ac. id/ index. php/ eol/ article/ view/3527/2558.

Soeriadiredja, Purwadi. 2013. "Marapu: Konstruksi Identitas Budaya Orang Sumba, NT". Antropolodg Indonesia: Indonesian Journal of Social and Cultural Anthropology 34 (1): 59- 73. http:// www.ijil. ui.ac.id/ index. php/ jai/ article/ view/3197/ 2497.

Syamsurijal. 2017. "Parupama/ ; Nasehat Yang Menghibur Pendahuluan Tradisi-Tradisi Sastranya Yang Berupa Lontara ( Tradisi Tulisan )". Jurnal Lektur Keagamaan 15 (2): 295-317. 